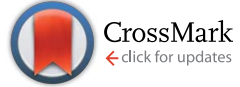

Cite this: RSC Adv., 2016, 6, 35257

Received 19th February 2016

Accepted 27th March 2016

DOI: $10.1039 / c 6 r a 04482 d$

www.rsc.org/advances

\section{Bisferrocenyl-functionalized pseudopeptides: access to separated ionic and electronic contributions for electrochemical anion sensing $\dagger$}

\author{
Mrituanjay D. Pandey, ${ }^{\text {ab }}$ Vicente Martí-Centelles, ${ }^{a}$ M. Isabel Burguete, ${ }^{a}$ \\ Noemí Montoya, ${ }^{C}$ Santiago V. Luis, ${ }^{* a}$ Enrique García-España*d \\ and Antonio Doménech-Carbó*c
}

Pseudopeptidic receptors containing ferrocene fragments have been prepared and their response to a series of anions was measured by a voltammetry of microparticles methodology. Such water-insoluble compounds yield anion-assisted reversible solid-state oxidations differing in their open-circuit potential and their midpeak potential recorded in cyclic voltammetric measurements. The difference between those potentials provides the individual thermodynamic contributions of electron and proton transfer, revealing that the mechanism of an ion-sensitive electrode can differ in potentiometry and voltammetry. The studied receptors are potentially interesting for potentiometric sensing, showing relatively high selectivity for $\mathrm{H}_{2} \mathrm{PO}_{4}{ }^{-}$and $\mathrm{HPO}_{4}{ }^{2-}$ anions.

\section{Introduction}

The design of chemical redox-active probes for the detection of non-electroactive species is of current interest. ${ }^{1}$ To achieve the selective binding and sensing of anions it is a key issue to design receptors properly fitting the electronic and steric features of a given anionic species. ${ }^{2}$ Various techniques can be used for the purpose of detecting the generated signals, being the electrochemical approach of particular interest. In this respect, the inclusion of neutral ferrocenyl fragments in anion receptors is very attractive due to their reversible electrochemical response. ${ }^{3}$

Amide groups are known to establish supramolecular interactions with anions. ${ }^{4-10}$ Taken this into account, pseudopeptidic structures are interesting targets for anion recognition being compatible with biological-like conditions, ${ }^{11}$ but currently, only one example of bisferrocenyl-functionalized peptides has been reported. ${ }^{12}$ Here we report the synthesis of a series of bisferrocenyl-functionalized pseudopeptides, Et-Val-Fc ${ }_{2}$ (4), But-Val-Fc ${ }_{2}$ (5), and Hexy-Val-Fc $c_{2}$ (6), as anion receptors. This

\footnotetext{
${ }^{a}$ Universitat Jaume I, Departamento de Química Inorgánica y Orgánica, Av. Sos Baynat, s/n, E-12071 Castellón, Spain. E-mail: luiss@uji.es; Fax: +34 964728214; Tel: +34 964728239

${ }^{b}$ Department of Chemistry, Dr H. S. Gour Central University, Sagar, MP 470003, India ${ }^{c}$ Departament de Química Analitica, Universitat de València, $\mathrm{Dr}$ Moliner, 50, Burjassot, 46100 València, Spain. E-mail: antonio.domenech@uv.es; Fax: +34 963544436; Tel: +34963544533

${ }^{d}$ Instituto de Ciencia Molecular, Universidad de Valencia, C/Catedrático José Beltrán no. 2 Paterna, 46980 Valencia, Spain.E-mail: enrique.garcia-es@uv.es

$\dagger$ Electronic supplementary information (ESI) available. See DOI: 10.1039/c6ra04482d
}

design is based on previous studies with receptors related to the pseudopeptides Et-Val (1), But-Val (2), and Hexy-Val (3) but containing fluorescent groups that have proved to exhibit selectivity for $\mathrm{H}_{2} \mathrm{PO}_{4}{ }^{-}$versus other anions such as $\mathrm{Cl}^{-}, \mathrm{Br}^{-}$, $\mathrm{CH}_{3} \mathrm{COO}^{-}$and $\mathrm{CF}_{3} \mathrm{COO}^{-}$and including $\mathrm{HSO}_{4}{ }^{-}$, at acidic $\mathrm{pH}$ values..$^{13-15}$

Electrochemical sensing involves, in general, coupled electron and ion transfer processes and so the determination of the parameters associated to individual charge transfer processes is of obvious interest. The separation of the Gibbs energies of electron and ion transfer has been done in the case of immiscible liquids and solutions: already in 2000, it has been shown that droplets of a ferrocene solution in nitrobenzene immobilized on a graphite electrode in an aqueous solution gives a voltammetric response where the Gibbs energies of electron and ion transfer can be separated. ${ }^{\mathbf{1 6}}$ This allows for the experimental determination of thermochemical properties for singleion solvation using direct polarization of liquid/liquid interfaces with two adjacent electrolyte-supported immiscible liquids, ${ }^{17}$ membrane-modified liquid-liquid interfaces, ${ }^{\mathbf{1 8 , 1 9}}$ large surface area, ${ }^{20}$ micro/nanohole,${ }^{21-24}$ and triple-phase boundary measurements at microdroplets immobilized on electrode surfaces. ${ }^{25-28}$

However, the separation of the thermochemical parameters for ion and electron transport has been revealed much more difficult in the case of solid compounds. In a recent report, Scholz et $a l^{29}$ have proved that in the case of a tungsten bronze electrode in contact with aqueous electrolytes, different mechanisms are responsible for the potentiometric and the voltammetric responses, involving, respectively, a proton transfer comparable to that occurring at glass electrodes, ${ }^{30,31}$ and simultaneous 
electron and ion transfer occurring at the metal/bronze and bronze/electrolyte interfaces. A similar approach was previously used for the separation of the Gibbs energies of electron and ion transfer in alkynyl-triphosphine tetranuclear $\mathrm{Au}(\mathrm{I})$ complexes containing ferrocenyl motifs, ${ }^{32}$ extending treatments prompting the determination of individual Gibbs energies of transfer of cation $^{33,34}$ and anion ${ }^{34,35}$ between two miscible solvents and define a solvent-independent potential scale. ${ }^{36-38}$

In this report, we describe the application of this methodology for obtaining separate thermochemical contributions for anion and electron transfer in bisferrocenyl-functionalized pseudopeptides, thus constituting the second system where this separation is made possible, and discuss such data in relation to the characteristics of electrochemical anion-sensing via ion-insertion processes. ${ }^{39-44}$

\section{Experimental}

\section{Materials and methods}

Electrochemical measurements were performed with $10^{-6}$ to $0.15 \mathrm{M}$ aqueous solutions of $\mathrm{NaCl}, \mathrm{NaHCO}_{3}, \mathrm{NaClO}_{4}, \mathrm{NaNO}_{3}$, $\mathrm{KNO}_{3}, \mathrm{Na}_{2} \mathrm{SO}_{4}, \mathrm{KH}_{2} \mathrm{PO}_{4}, \mathrm{~K}_{2} \mathrm{HPO}_{4}$, and $\mathrm{K}_{3} \mathrm{PO}_{4}$ (all analytical grade Merck reagents). Solid-state electrochemical experiments were performed by mechanically transferring small amounts of the solid specimens to the surface of paraffin-impregnated graphite electrodes following the procedures already reported. ${ }^{45-47}$ Voltammetric measurements were performed at 298 $\pm 1 \mathrm{~K}$ in a conventional three-electrode cell under argon atmosphere using a $\mathrm{CH}$ I660 potentiostat coupled to a conventional three-electrode cell with Pt auxiliary electrode and $\mathrm{AgCl}$ (3 $\mathrm{M} \mathrm{NaCl}$ /Ag reference electrode.

Microparticulate cluster deposits were examined with a Jeol JSM 6300 scanning electron microscope operating with a LinkOxford-Isis X-ray microanalysis system (SEM/EDX). The analytical conditions were: accelerating voltage $20 \mathrm{kV}$, beam current 2 $\times 10^{-9} \mathrm{~A}$, and, working distance $15 \mathrm{~mm}$. Samples were carbon coated to eliminate charging effects. Semiquantitative microanalysis was carried out using the ZAF method for correcting interelemental effects. The counting time was $100 \mathrm{~s}$ for major and minor elements.

\section{Molecular modeling}

Molecular models were carried out using Spartan'08.8 Conformational searches were carried out using the Monte Carlo algorithm using the Merck molecular force field. The hostguest interaction energies were calculated from the energies of the most stable conformers obtained by using the following equation: $E$ (interaction) $=E$ (host-guest complex $)-E$ (host $)-$ $E$ (guest). ${ }^{48,49}$

\section{Synthesis of compounds}

Synthesis of 4-6. The corresponding pseudopeptide $(0.258 \mathrm{~g}$ for $1,0.286 \mathrm{~g}$ for 2 or $0.314 \mathrm{~g}$ for $3 ; 1.0 \mathrm{~mol}$ ) was dissolved in of methanol $(20 \mathrm{~mL})$ to form a clear solution that was added into a methanol solution $(50 \mathrm{~mL})$ of 1 -ferrocenecarboxaldeyde $(0.428$ $\mathrm{g}, 2.0 \mathrm{mmol})$. It was allowed to react for $4 \mathrm{~h}$ at $\mathrm{rt}$. Then, the reaction mixture was treated with a methanolic solution of $\mathrm{NaBH}_{4}(0.148 \mathrm{~g}, 4.0 \mathrm{mmol})$ and it was allowed to react for $2 \mathrm{~h}$. Then, the solvent was removed under reduced pressure and the residue was washed with diethyl ether $(2 \times 20 \mathrm{~mL})$. The crude product was dissolved in benzene and precipitated with $n$ hexane to yield the pure product as a brown solid.

Compound Et-Val-Fc ${ }_{2}$ (4). 4 (0.430 g, 67\% yield). Mp 161-163 ${ }^{\circ} \mathrm{C}$ (decomposition). $[\alpha]_{\mathrm{D}}^{25}=+16.32\left(c 0.01, \mathrm{CH}_{2} \mathrm{Cl}_{2}\right.$ ). IR (ATR): 487, 496, 514, 559, 592, 674, 814, 999, 1098, 1239, 1442, 1546, 1634, 1664, 2961, $3076 \mathrm{~cm}^{-1} .{ }^{1} \mathrm{H}$ NMR (500 MHz, $\left.\mathrm{C}_{6} \mathrm{D}_{6}\right) \delta 0.96$ $(6 \mathrm{H}, \mathrm{d}, J=6.9 \mathrm{~Hz}), 0.98(6 \mathrm{H}, \mathrm{d}, J=6.9 \mathrm{~Hz}), 1.58(2 \mathrm{H}, \mathrm{dd}, J=6.6$, $11.6 \mathrm{~Hz}), 2.05-2.15(2 \mathrm{H}, \mathrm{m}), 3.01(2 \mathrm{H}, \mathrm{t}, J=4.8 \mathrm{~Hz}), 3.20-3.26$ $(2 \mathrm{H}, \mathrm{m}), 3.30(2 \mathrm{H}, \mathrm{dd}, J=7.0,12.8 \mathrm{~Hz}), 3.33-3.41(2 \mathrm{H}, \mathrm{m}), 3.51$ $(2 \mathrm{H}, \mathrm{dd}, J=6.7,12.8 \mathrm{~Hz}), 3.99(4 \mathrm{H}, \mathrm{s}), 4.09(10 \mathrm{H}, \mathrm{s}), 4.16(2 \mathrm{H}, \mathrm{s})$, $4.22(2 \mathrm{H}, \mathrm{s}), 7.40(2 \mathrm{H}, \mathrm{s}) \mathrm{ppm} .{ }^{13} \mathrm{C} \mathrm{NMR}\left(126 \mathrm{MHz}, \mathrm{C}_{6} \mathrm{D}_{6}\right) \delta 19.1$, 20.5, 32.6, 40.6, 49.2, 68.6, 68.8, 69.0, 69.1, 69.1, 69.4, 88.0, 175.0 ppm. HRMS (ESI-TOF) ${ }^{+}$calc. for $\mathrm{C}_{34} \mathrm{H}_{47} \mathrm{Fe}_{2} \mathrm{~N}_{4} \mathrm{O}_{2}(\mathrm{M}+\mathrm{H})^{+}$ 655.2398; found: 655.2384. Anal. calcd for $\left[4+4 \mathrm{H}_{2} \mathrm{O}\right]$ $\mathrm{C}_{34} \mathrm{H}_{54} \mathrm{Fe}_{2} \mathrm{~N}_{4} \mathrm{O}_{6}$; found; C, 56.32; H, 7.12; N, 7.62; calculated; C, 56.21; H, 7.49; N, 7.71.

Compound But-Val-Fc $\mathbf{2}_{2}$ (5). 5 (0.440 g, 65\% yield). Mp 141$142{ }^{\circ} \mathrm{C}$ (decomposition). $[\alpha]_{\mathrm{D}}^{25}=-3.41$ ( c 0.005, $\mathrm{CH}_{2} \mathrm{Cl}_{2}$ ). IR (ATR): 486, 497, 514, 559, 594, 811, 997, 1103, 1236, 1445, 1555, 1643, 1670, 2962, 3076, $3293 \mathrm{~cm}^{-1} .{ }^{1} \mathrm{H}$ NMR (500 MHz, $\mathrm{C}_{6} \mathrm{D}_{6}$ ) $\delta 0.65(6 \mathrm{H}, \mathrm{d}, J=6.9 \mathrm{~Hz}), 0.68(6 \mathrm{H}, \mathrm{d}, J=6.9 \mathrm{~Hz}), 1.02(4 \mathrm{H}, \mathrm{dd}, J$ $=6.6,10.1 \mathrm{~Hz}), 1.75-1.85(2 \mathrm{H}, \mathrm{m}), 2.66(2 \mathrm{H}, \mathrm{d}, J=4.9 \mathrm{~Hz}), 2.89$ $(4 \mathrm{H}, \mathrm{q}, J=6.4 \mathrm{~Hz}), 2.97(2 \mathrm{H}, \mathrm{d}, J=12.9 \mathrm{~Hz}), 3.15(2 \mathrm{H}, \mathrm{d}, J=12.9$ $\mathrm{Hz}$ ), 3.66-3.71 (4H, m), 3.77 (9H, s), 3.78-3.81 (2H, m), 3.82-3.85 $(2 \mathrm{H}, \mathrm{m}), 6.46(2 \mathrm{H}, \mathrm{t}, J=6.3 \mathrm{~Hz}) \mathrm{ppm} .{ }^{13} \mathrm{C} \mathrm{NMR}\left(75 \mathrm{MHz}, \mathrm{C}_{6} \mathrm{D}_{6}\right)$ $\delta$ 18.1, 19.5, 27.3, 31.6, 38.3, 48.2, 67.6, 67.8, 67.9, 68.1, 68.1, 68.5, 87.0, 172.8 ppm. HRMS (ESI-TOF) ${ }^{+}$calc. for $\mathrm{C}_{36} \mathrm{H}_{51} \mathrm{Fe}_{2} \mathrm{~N}_{4} \mathrm{O}_{2}$ $(\mathrm{M}+\mathrm{H})^{+}$683.2711; found: 683.2719. Anal. calcd $\left[5+\mathrm{H}_{2} \mathrm{O}\right]$ $\mathrm{C}_{36} \mathrm{H}_{52} \mathrm{Fe}_{2} \mathrm{~N}_{4} \mathrm{O}_{3}$; found; C, 61.94; $\mathrm{H}, 7.58 ; \mathrm{N}, 8.02$; calculated; C, 61.72; H, 7.48; N, 8.00.

Compound Hexy-Val-Fc 2 (6). 6 (0.500 g, 71\% yield). Mp 79-81 ${ }^{\circ} \mathrm{C}$ (decomposition). $[\alpha]_{\mathrm{D}}^{25}=+4.8\left(c 0.002, \mathrm{CH}_{2} \mathrm{Cl}_{2}\right)$. IR (ATR): 472, 497, 522, 524, 549, 595, 688, 811, 997, 1019, 1103, 1228, 1361, 1457, 1518, 635, 2860, 2932, $3316 \mathrm{~cm}^{-1} .{ }^{1} \mathrm{H} \mathrm{NMR}(500 \mathrm{MHz}$, $\left.\mathrm{C}_{6} \mathrm{D}_{6}\right) \delta 0.97(6 \mathrm{H}, \mathrm{d}, J=6.9 \mathrm{~Hz}), 1.00(6 \mathrm{H}, \mathrm{d}, J=6.9 \mathrm{~Hz}), 1.15-$ $1.23(4 \mathrm{H}, \mathrm{m}), 1.31-1.39$ (4H, m), 2.08-2.16 (2H, m), $2.99(2 \mathrm{H}, \mathrm{d}, J$ $=4.9 \mathrm{~Hz}), 3.24(4 \mathrm{H}, \mathrm{dd}, J=6.6,10.9 \mathrm{~Hz}), 3.28(2 \mathrm{H}, \mathrm{d}, J=13.4$ $\mathrm{Hz}), 3.47(2 \mathrm{H}, \mathrm{d}, J=12.8 \mathrm{~Hz}), 3.98(4 \mathrm{H}, \mathrm{dd}, J=2.0,6.8 \mathrm{~Hz}), 4.06$ (10H, s), 4.09 (2H, s), $4.15(2 \mathrm{H}, \mathrm{s}), 6.87(2 \mathrm{H}, \mathrm{t}, J=5.8 \mathrm{~Hz}) \mathrm{ppm}$. ${ }^{13} \mathrm{C}$ NMR (75 MHz, $\mathrm{C}_{6} \mathrm{D}_{6}$ ) $\delta 18.1,19.5,25.9,29.8,31.6,38.2,48.2$, 67.6, 67.8, 67.9, 68.0, 68.2, 68.4, 87.0, 172.7 ppm. HRMS (ESITOF $)^{+}$calc. for $\mathrm{C}_{38} \mathrm{H}_{55} \mathrm{Fe}_{2} \mathrm{~N}_{4} \mathrm{O}_{2}(\mathrm{M}+\mathrm{H})^{+}$711.3024; found: 711.3009. Anal. calcd $\left[6+6 \mathrm{H}_{2} \mathrm{O}\right] \mathrm{C}_{38} \mathrm{H}_{66} \mathrm{Fe}_{2} \mathrm{~N}_{4} \mathrm{O}_{8}$; found; $\mathrm{C}$, 55.61; H, 8.04; N, 6.81; calculated; C, 55.75; H, 8.13; N, 6.84.

\section{Results and discussion}

\section{Synthesis and characterization}

The starting $C_{2}$ symmetric pseudopeptides 1-3 were synthesized as previously reported..$^{13-15}$ Compounds 1-3 were reacted in methanol with 1-ferrocenecarboxaldeyde at room temperature for four hours. Then, the reaction mixture was treated with $\mathrm{NaBH}_{4}$ for two additional hours. After appropriate purification, 

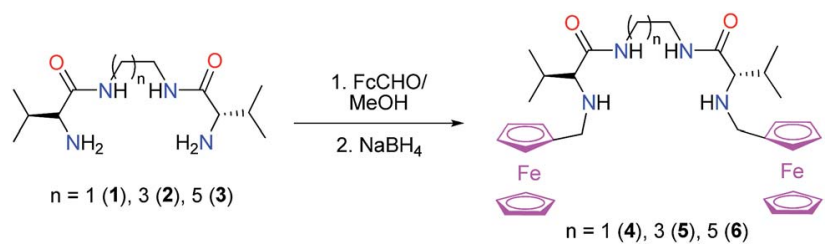

Scheme 1 Synthesis of pseudopeptidic receptors.

the desired products 4-6 were obtained as solids in $60-70 \%$ yield (Scheme 1).

\section{Electrochemical behavior}

The cyclic voltammetric response for the studied receptors in contact with different aqueous electrolytes is illustrated in Fig. 1 for the case of microparticulate films of $\mathbf{4}$ and $\mathbf{5}$ in contact with a $0.10 \mathrm{M} \mathrm{K}_{2} \mathrm{HPO}_{4}$ aqueous solution. In the case of 4 , in the initial positive-going potential scan, an oxidation peak appears at a potential of $+0.50 \mathrm{~V} v s$. $\mathrm{Ag} / \mathrm{AgCl}\left(E_{\mathrm{pa}}^{1 \mathrm{st}}\right)$, followed, in the subsequent negative-going scan by a cathodic peak at $+0.24 \mathrm{~V}$. Upon repetitive cycling the potential scan, this peak remains stable and appears coupled to an anodic peak at $+0.36 \mathrm{~V}$, defining a well-defined couple whose anodic $\left(E_{\mathrm{pa}}\right)$ and cathodic $\left(E_{\mathrm{pc}}\right)$ peak potentials become stable, defining a midpeak potential, $E_{\mathrm{mp}}=\left(\left(E_{\mathrm{pc}}+E_{\mathrm{pa}}\right) / 2\right)$ that remains independent on potential scan rate in the range between 2 and $10000 \mathrm{mV} \mathrm{s}^{-1}$. In the case of 5, the first and subsequent anodic scans display essentially the same peak potential, defining with the coupled cathodic peak an essentially reversible pair, as judged by the peak potential separation, tending to $60 \mathrm{mV}$ at low scan rates and the independence of the midpeak potential on the sweep rate.

In the case of $\mathbf{4}$, the peak potential separation for the stable couple, $\Delta E_{\mathrm{p}}=\left(E_{\mathrm{pa}}-E_{\mathrm{pc}}\right)$, is larger than the reversible value (59/ $n \mathrm{mV}$ at $298 \mathrm{~K}$ ) and increases on increasing the potential scan rate, but tends to $\Delta E_{\mathrm{p}}=60 \mathrm{mV}$ at low potential scan rates, as can

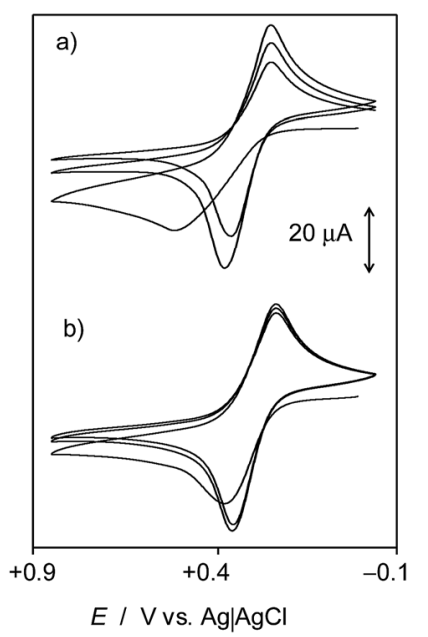

Fig. 1 Cyclic voltammograms of microparticulate films of: (a) 4 and (b) 5 on a glassy carbon electrode immersed into $0.10 \mathrm{M} \mathrm{K}_{2} \mathrm{HPO}_{4}$. Potential scan rate $50 \mathrm{mV} \mathrm{s}^{-1}$. be seen in Fig. 2. These features can be associated to an essentially reversible behavior distorted by uncompensated ohmic drops in the cell. Consistently, square wave voltammograms showed a unique peak that becomes unchanged in repetitive voltammetry and becomes only slightly shifted in the positive direction of potentials on increasing the square wave frequency. The voltammetric response of the studied bisferrocenyl-functionalized pseudopeptides was between those depicted in Fig. $1 \mathrm{a}$ and $\mathrm{b}$ for all tested anions: $\mathrm{Cl}^{-}, \mathrm{ClO}_{4}{ }^{-}, \mathrm{NO}_{3}{ }^{-}$, $\mathrm{SO}_{4}{ }^{2-}, \mathrm{H}_{2} \mathrm{PO}_{4}{ }^{-}, \mathrm{HPO}_{4}{ }^{2-}$.

The intensity of the voltammetric peaks increased on increasing the amount of deposited pseudopeptide until remaining essentially constant for electrode surface coverage of ca. $2.5 \mathrm{mg} \mathrm{cm}^{-2}$ (see ESI $\dagger$ ). This feature is consistent with the description of the involved electrochemical processes by Lovric, Scholz, Oldham et al. ${ }^{\mathbf{5 0 - 5 4}}$ in terms of electron transfer through the solid/electrode interface coupled to ion transfer across the solid/electrolyte interface so that only the layer of particles in direct contact with the base electrode become electroactive.

The peak potential of the initial anodic scan, $E_{\mathrm{pa}}^{1 \text { st }}$, is slightly more positive than the stable $E_{\mathrm{pa}}$ value recorded in repetitive voltammetry and defines an apparent midpeak potential, $E_{\mathrm{mp}}^{1 \mathrm{st}}\left(=\left(E_{\mathrm{pc}}+E_{\mathrm{pa}}^{1 \mathrm{st}}\right) / 2\right)$ which is positively shifted on increasing the potential sweep rate, as can be seen in Fig. 2. Here, $E_{\mathrm{pa}}, E_{\mathrm{pc}}, E_{\mathrm{mp}}$ and $E_{\mathrm{mp}}^{1 \text { st }}$ values are plotted $v s$. the inverse of the square root of the potential scan rate, $v^{-1 / 2}$, to clearly illustrate the tendencies at low and high scan rates. This peculiar $1^{\text {st }}$ scan behavior could be tentatively associated to double-layer charging effects, with the removal of some product from the electrode surface.

In order to test their availability for potentiometric sensing, open-circuit potentials (OCP) were measured. As observed for alkynyl-triphosphine tetranuclear $\mathrm{Au}(\mathrm{I})$ complexes containing ferrocenyl motifs, ${ }^{32}$ the potential measured for bisferrocenylfunctionalized pseudopeptides varied slowly with time, presumably due to transient concentration gradients established in the double layer, tending to a stationary state at large

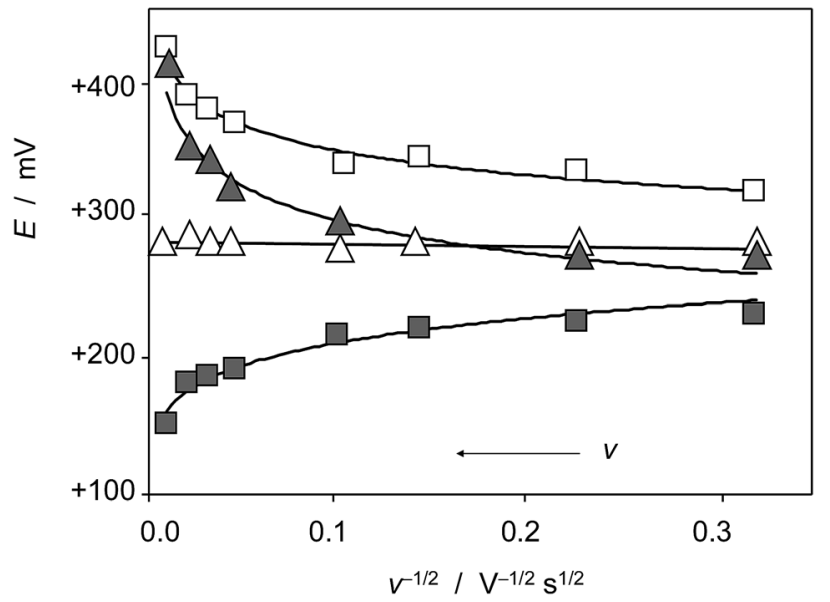

Fig. 2 Variation of the values of $E_{\mathrm{pa}}$ (squares), $E_{\mathrm{pc}}$ (solid squares), $E_{\mathrm{mp}}$ (triangles) and $E_{\mathrm{mp}}^{1 \text { st }}$ (solid triangles) values on $v^{-1 / 2}$ for cyclic voltammograms of a microparticulate films of 4 in contact with $0.10 \mathrm{M}$ $\mathrm{K}_{2} \mathrm{HPO}_{4}$. 
times. Interestingly, application of an oxidative conditioning step at a constant potential (in the following, conditioning potential, $E_{\text {cond }}$ ) between +0.20 and $+0.60 \mathrm{~V}$ or repetitive cycling the potential around the midpeak potential, produced potential/time variations much slower than those recorded at freshly prepared electrodes, as can be seen in Fig. 3. The limiting, infinite time, OCP value (in the following, $E_{\text {OCP }}$ ) was obtained by extrapolating at $t^{-1} \rightarrow 0$ the $E v s . t^{-1}$ plots from experimental data. This value was dependent, however, on the applied conditioning potential. The values of $E_{\mathrm{OCP}}$ thus measured remained unchanged after application of oxidative conditioning steps longer than 90-120 s and accordingly conditioning times of 5 min were routinely performed.

As will be discussed in the following section, the application of an oxidative conditioning potential should yield a layer of the anion-permeated oxidized form of the solid which, under OCP measurements, will equilibrate with the adjacent $\mathrm{X}^{m-}$-containing solution. For obtaining potentiometrically representative $E_{\text {OCP }}$ values, the conditioning potential was selected in all cases to that corresponding to the $E_{\mathrm{mp}}$ recorded in cyclic voltammograms to ensure that the thermochemical activities of the oxidized and reduced forms of the solid become equal (vide infra). Consistently, the variation of the $E_{\mathrm{OCP}}$ values on the conditioning potential, $E_{\text {cond }}$, fits to s-shaped curves, the intermediate OCP corresponding just to that obtained at a conditioning potential equal to $E_{\mathrm{mp}}$, as can be seen in Fig. 4 .

\section{Assessment of anion insertion}

In order to assess the solid state nature of the involved electrochemical processes, SEM/EDX examination of microparticulate deposits on a graphite bar of the clusters before and after oxidative electrolysis at a potential $100 \mathrm{mV}$ more positive than $E_{\mathrm{pa}}^{1 \text { st }}$ was performed in contact with different electrolytes. Fig. 5 shows the corresponding data for the film from 5 in contact with $0.10 \mathrm{M} \mathrm{NaClO}_{4}$. The pristine film consisted of irregular crystals of smooth surface, as can be seen in Fig. 5a. After oxidative electrolysis, the crystals, in general, decreased in size and presented terraces in their surface and often concavities (see Fig. 5b). Quantitative SEM/EDX analysis (see Fig. 6)

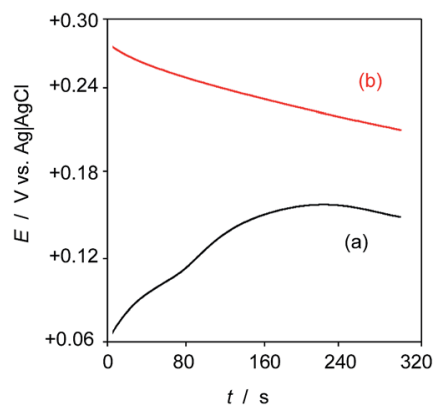

Fig. 3 Initial portion of the OCP vs. time curves for microparticulate films of 4 in contact with $0.10 \mathrm{M} \mathrm{K}_{2} \mathrm{HPO}_{4}$. (a) Freshly prepared electrode; (b) electrode conditioned by previous cycling the potential (four cycles) between +0.05 and $+0.65 \mathrm{~V}$ at $50 \mathrm{mV} \mathrm{s}^{-1}$.

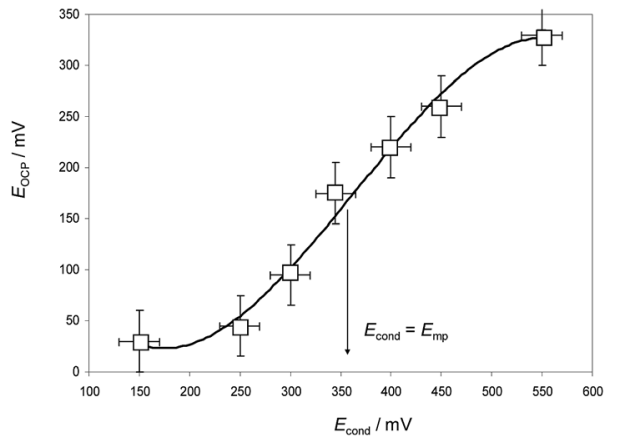

Fig. 4 Variation of $E_{\mathrm{OCP}}$ with the conditioning potential applied from 5 min to microparticulate films of 5 on GCE immersed into $0.10 \mathrm{M}$ $\mathrm{NaClO}_{4}$.
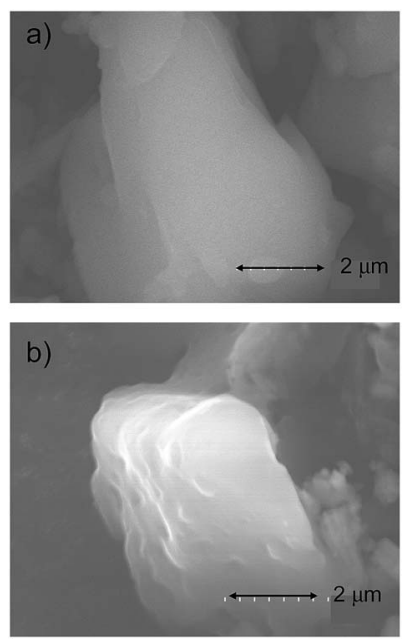

Fig. 5 SEM images for a microparticulate deposit of 5 on a graphite bar (a) before and (b) after $10 \mathrm{~min}$ of electrolysis at $+0.50 \mathrm{~V}$ in contact with $0.10 \mathrm{M} \mathrm{NaClO}_{4}$.

confirmed the presence of $\mathrm{Cl}$ in the crystals, thus confirming the insertion of foreign anions into them.

\section{Separating ionic and electronic contributions}

The above OCP and $\mathrm{CV}$ features can be rationalized on considering the peculiar solid-state nature of the electrochemical processes involved in the voltammetry of microparticles methodology, ${ }^{45-47}$ assuming that, in the case of electroactive ion-permeable solids experiencing a redox solid-to-solid transformation, the process initiates at the three-phase electrode/ solid particle/electrolyte boundary and propagates through the solid via electron hopping between immobile redox centers and ion migration within the solid. ${ }^{50-54}$

Based on molecular modeling (vide infra), one can assume that anions are stabilized forming $1: 1$ complexes eventually involving protonation of the polyamine chain. Then, assuming that both the oxidized and reduced solid forms are insoluble in the $\mathrm{X}^{m-}$-containing electrolyte, the overall equilibrium established during the electrochemical turnovers can be represented as: 

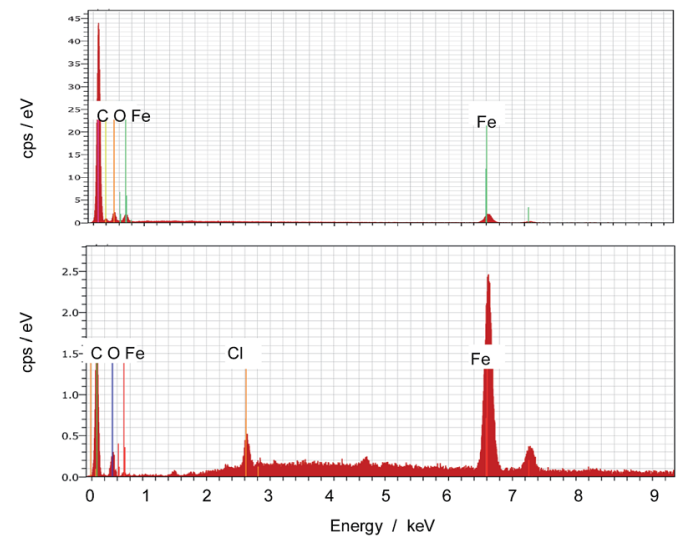

Fig. 6 SEM/EDX analysis of 5 particles deposited onto on a graphite bar (a) before, and, (b) after 10 min of electrolysis at $+0.50 \mathrm{~V}$ in contact with $0.10 \mathrm{M} \mathrm{NaClO}_{4}$.

$$
\{\mathrm{L}\}_{\text {solid }}+z \mathrm{H}_{\mathrm{aq}}{ }^{+}+\mathrm{X}_{\mathrm{aq}}{ }^{m-} \leftrightarrows\left\{\mathrm{LH}_{z}{ }^{m+} \cdots \mathrm{X}^{m-}\right\}_{\text {solid }}+(m-z) \mathrm{e}^{-}
$$

In these cases, the advance of the electrochemical process involves the permeation of the pristine solid, $\{\mathrm{L}\}$, by the electrolyte anions, $\mathrm{X}^{m-}$. As a result, the formation of a surface layer of oxidized, $\mathrm{X}^{m-}$-permeated compound, $\left\{\mathrm{LH}_{z}^{m+} \cdots \mathrm{X}^{m-}\right\}$, forming either mixed crystals ${ }^{55,56}$ or segregated layers ${ }^{57,58}$ of the oxidized and reduced solid forms is possible. In the first case, the thermodynamic activities of the solid species can be taken as proportional to their molar fractions, while in the second, the thermodynamic activities of the components should be considered as unit. SEM images, as well as data on the charge passed in voltammetric experiments (typically of $20 \mu \mathrm{C}$ ) suggested that the electrochemical reactions were confined at a relatively narrow region near the external surface of the solid pseudopeptides occupying a volume of $c a .1-2 \%$ of the crystals (typically $2 \mu \mathrm{m}$ sized). For the process described by eqn (1), the midpeak potential measured in voltammetric experiments should satisfy the relationship:

$$
E_{\mathrm{mp}}=E_{\mathrm{EX}}^{\circ}+\frac{R T}{(m-z) F} \ln \frac{a_{\left\{\mathrm{LH}_{z} \cdots \mathrm{X}^{m-}\right\}}}{a_{\{\mathrm{L}\}} a_{\mathrm{H}^{+}}^{z} a_{\mathrm{X}^{m-}}}
$$

where $E_{\mathrm{EX}}^{\circ}$ represents the formal electrode potential of the couple. Accordingly, the Gibbs free energy for the process described by eqn (1), $\Delta G_{\mathrm{EX}}$ could be estimated applying the Nernst equation providing that the value of $E_{\mathrm{EX}}^{\circ}$ was known.

Now, let us consider a microparticulate deposit of the solid pseudopeptide receptor $\{\mathrm{L}\}$ which is in contact with a $\mathrm{X}^{m-}$ containing aqueous electrolyte after the oxidative conditioning previously described so that a layer of $\mathrm{X}^{m-}$-doped oxidized complex was formed, as schematically depicted in Scheme 2 . Under the conditions of OCP measurements, an interfacial equilibrium analogue to that described for tungsten bronze electrode $^{29}$ and glass electrode $\mathrm{e}^{\mathbf{3 0 , 3 1}}$ is established at the crystal/ electrolyte interface:

$$
\left\{\mathrm{LH}_{z}{ }^{m+} \cdots \mathrm{X}^{m-}\right\}_{\text {solid }} \leftrightarrows\left\{\mathrm{LH}_{z}{ }^{m+}\right\}_{\text {solid }}+\mathrm{X}_{\mathrm{aq}}{ }^{m-}
$$

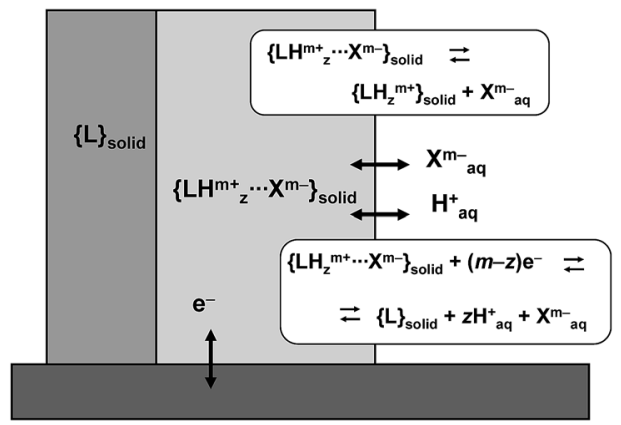

Scheme 2 Schematics for the processes involving separate ionic (OCP measurements) and coupled ionic plus electronic transfer (CV measurements) in a L-modified electrode conditioned by repetitive cycling of the potential in a solution containing $X^{m-}$ ions.

Formally, the process described by eqn (3) can be obtained as the combination of the electron transfer process described by eqn (1) and:

$$
\{\mathrm{L}\}_{\text {solid }}+z \mathrm{H}_{\mathrm{aq}}{ }^{+} \leftrightarrows\left\{\mathrm{LH}_{z}{ }^{m+}\right\}_{\text {solid }}+(m-z) \mathrm{e}^{-}
$$

For this last process, the Nernst equation can be written as:

$$
E_{\mathrm{ET}}=E_{\mathrm{ET}}^{\circ}+\frac{R T}{m-z F} \ln \frac{a_{\left\{\mathrm{LH}_{z}{ }^{m+}\right\}}}{a_{\{\mathrm{L}\}} a_{\mathrm{H}^{+}}{ }^{z}}
$$

Accordingly, the OCP can be expressed from the Nernst equation for the process described by eqn (3):

$$
E_{\mathrm{OCP}}=E_{\mathrm{XT}}^{\circ}+\frac{R T}{(m-z) F} \ln \frac{a_{\left\{\mathrm{LH}_{z}^{m+}\right\}} a_{\mathrm{X}^{m-}}}{a_{\left\{\mathrm{LH}_{z} \cdots \mathrm{X}^{m-}\right\}}}
$$

The measured OCP also contains the potential drops at the base electrode $/\left\{\mathrm{LH}_{z}{ }^{m+}\right\}$ and the $\left\{\mathrm{LH}_{z}{ }^{m+}\right\} /\left\{\mathrm{LH}_{z}{ }^{m+} \cdots \mathrm{X}^{m-}\right\}$ interfaces, as well as the potential of the reference electrode. These potentials will not be considered because they remain constant in all measurements. Under the aforementioned conditions of electrode conditioning (i.e., applying a conditioning potential, $E_{\text {cond }}$, equal to the midpeak potential, $E_{\mathrm{mp}}$, see Fig. 4 ), and in contact with a solution containing $\mathrm{X}^{m-}$ in a sufficiently large concentration, the ratio $\frac{a^{\prime}{ }_{\left\{\mathrm{LH}_{z}{ }^{m+}\right\}}}{a_{\left\{\mathrm{LH}_{z}{ }^{m+} \ldots \mathrm{X}^{m-}\right\}}}$ can be considered as being essentially constant and equal to one, so that the anionindependent formal potential for the electron transfer process (eqn (5)), $E_{\mathrm{ET}}^{\circ}$, can be calculated as the difference between the voltammetric midpeak potential, $E_{\mathrm{mp}}$, and the OCP:

$$
E_{\mathrm{e}}=E_{\mathrm{Ex}}^{\circ}-E_{\mathrm{XT}}^{\circ}=E_{\mathrm{mp}}-E_{\mathrm{OCP}}
$$

Consistently with the above theoretical treatment, combination of our voltammetric and OCP data provide an anionindependent $E_{\mathrm{e}}$ value for each pseudopeptide receptor within the range of experimental error (see Table 1 ).

The values of $E_{\mathrm{e}}$ increase in the order $\mathbf{4}<\mathbf{5}<\mathbf{6}$ regardless the anion. This second feature is consistent with the relation of this 
Table 1 Formal electrode potentials for the pseudopeptide receptors in this study in contact with aqueous solutions of different $X^{m-}$ anions measured from voltammetric $\left(E_{\mathrm{mp}}\right)$ and open-circuit potential $\left(E_{\mathrm{OCP}}\right)$ data and $E_{\mathrm{e}}$ values calculated from the above

\begin{tabular}{llllr}
\hline Receptor/anion & Potential & $\mathbf{4}$ & $\mathbf{5}$ & \multicolumn{1}{c}{$\mathbf{6}$} \\
\hline $\mathrm{Cl}^{-}$ & $E_{\mathrm{mp}}(\mathrm{mV})$ & $320 \pm 5$ & $405 \pm 5$ & $440 \pm 5$ \\
$\mathrm{Cl}^{-}$ & $E_{\mathrm{OCP}}(\mathrm{mV})$ & $200 \pm 5$ & $250 \pm 5$ & $260 \pm 5$ \\
$\mathrm{Cl}^{-}$ & $E_{\mathrm{e}}(\mathrm{mV})$ & $120 \pm 7$ & $155 \pm 7$ & $180 \pm 7$ \\
$\mathrm{ClO}_{4}{ }^{-}$ & $E_{\mathrm{mp}}(\mathrm{mV})$ & $330 \pm 5$ & $355 \pm 5$ & $360 \pm 5$ \\
$\mathrm{ClO}_{4}{ }^{-}$ & $E_{\mathrm{OCP}}(\mathrm{mV})$ & $210 \pm 5$ & $195 \pm 5$ & $180 \pm 5$ \\
$\mathrm{ClO}_{4}{ }^{-}$ & $E_{\mathrm{e}}(\mathrm{mV})$ & $120 \pm 7$ & $160 \pm 7$ & $180 \pm 7$ \\
$\mathrm{NO}_{3}{ }^{-}$ & $E_{\mathrm{mp}}(\mathrm{mV})$ & $395 \pm 5$ & $430 \pm 5$ & $455 \pm 5$ \\
$\mathrm{NO}_{3}{ }^{-}$ & $E_{\mathrm{OCP}}(\mathrm{mV})$ & $275 \pm 5$ & $270 \pm 5$ & $270 \pm 5$ \\
$\mathrm{NO}_{3}{ }^{-}$ & $E_{\mathrm{e}}(\mathrm{mV})$ & $120 \pm 7$ & $160 \pm 7$ & $185 \pm 7$ \\
$\mathrm{SO}_{4}{ }^{2-}$ & $E_{\mathrm{mp}}(\mathrm{mV})$ & $240 \pm 5$ & $260 \pm 5$ & $275 \pm 5$ \\
$\mathrm{SO}_{4}{ }^{2-}$ & $E_{\mathrm{OCP}}(\mathrm{mV})$ & $115 \pm 5$ & $100 \pm 5$ & $95 \pm 5$ \\
$\mathrm{SO}_{4}{ }^{2-}$ & $E_{\mathrm{e}}(\mathrm{mV})$ & $125 \pm 7$ & $160 \pm 7$ & $180 \pm 7$ \\
& & & &
\end{tabular}

quantity, via Nernst equation, to the variation of Gibbs energy associated to the electron transfer process described by eqn (4). To rationalize the relative order in the $E_{\mathrm{e}}$ values, one can use the thermochemical cycle depicted in Scheme 3.

Here, the variation of Gibbs energy for the electron transfer in solid state, $\Delta G_{\mathrm{e}}^{\circ}$ (solid), is related to the Gibbs energies for electron transfer in the gas phase, $\Delta G_{\mathrm{e}}$ (gas), those for the vaporization of the $\mathrm{L}$ and $\mathrm{LH}_{z}$ species, $\Delta G_{\mathrm{vap}}^{\circ}(\mathrm{L}), \Delta G_{\mathrm{vap}}^{\circ}\left(\mathrm{LH}_{z}\right)$, respectively, proton hydration, $\Delta G_{\text {hyd }}^{\circ}\left(\mathrm{H}^{+}\right)$, and that for electron transfer from the gas phase to the electrode, $\Sigma_{\mathrm{e}}$.

$$
\begin{aligned}
\Delta G_{\mathrm{e}}^{\circ}(\text { solid })= & \Delta G_{\mathrm{e}}(\text { gas })+\Delta G_{\mathrm{vap}}^{\circ}\left(\mathrm{LH}_{z}\right)-\Delta G_{\mathrm{vap}}^{\circ}(\mathrm{L}) \\
& -\Delta G_{\mathrm{hyd}}^{\circ}\left(\mathrm{H}^{+}\right)+\Sigma_{\mathrm{e}}
\end{aligned}
$$

Since the terms $\Sigma_{\mathrm{e}}$ and $\Delta G_{\mathrm{hyd}}^{\circ}\left(\mathrm{H}^{+}\right)$are the same for all three pseudopeptides, the differences in and hence those in $E_{\mathrm{e}}$, result from balancing the differences in $\Delta G_{\mathrm{e}}$ (gas), $\Delta G_{\mathrm{vap}}^{\circ}(\mathrm{L})$ and $\Delta G_{\text {vap }}^{\circ}\left(\mathrm{LH}_{z}\right)$. These can be attributed to the different inductive effect associated to the aliphatic chain in turn influencing the differences in the Gibbs energies of vaporization mainly due to the different molecular polarizability. Roughly, the increase of the length of the aliphatic chain $(\mathbf{4}<\mathbf{5}<\mathbf{6})$ should produce an increase of the absolute values of both $\Delta G_{\text {vap }}^{\circ}(\mathrm{L})$ and $\Delta G_{\mathrm{vap}}^{\circ}\left(\mathrm{LH}_{z}\right)$, but also of those of $\Delta G_{\mathrm{e}}$ (gas). The overall result would be the stabilization of the solid protonated form (making $E_{\mathrm{e}}$ larger and $\Delta G_{\mathrm{e}}^{\circ}($ solid) more negative) in the order $\mathbf{4}<\mathbf{5}<\boldsymbol{6}$.

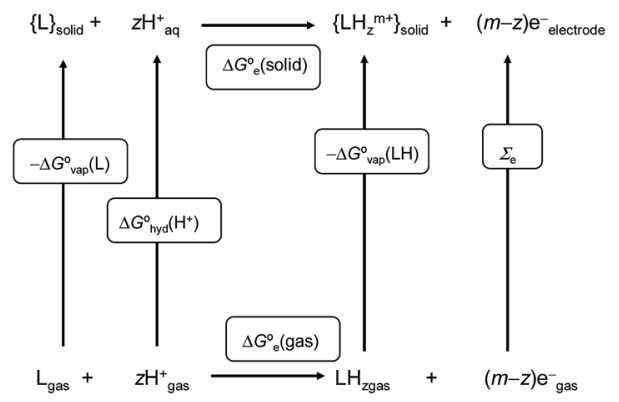

Scheme 3 Thermochemical cycle for the anion-independent electron transfer process described by eqn (4).

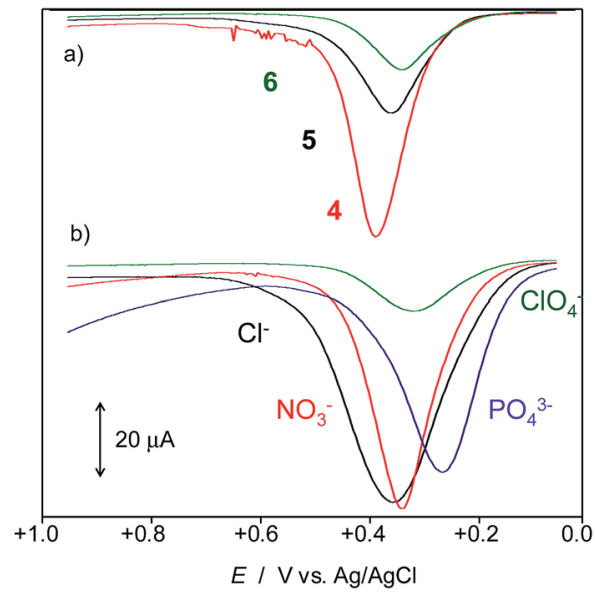

Fig. 7 Square wave voltammograms of: (a) 4-6 in contact with $0.10 \mathrm{M}$ $\mathrm{NaCl}$; (b) 5-modified electrodes immersed into $0.10 \mathrm{M}$ solutions of $\mathrm{NaCl}, \mathrm{KNO}_{3}, \mathrm{NaClO}_{4}$, and $\mathrm{K}_{2} \mathrm{HPO}_{4}$. Potential scan initiated at $+0.05 \mathrm{~V}$ in the positive direction. Potential step increment $4 \mathrm{mV}$; square wave amplitude $25 \mathrm{mV}$; frequency $10 \mathrm{~Hz}$.

\section{Anion sensing}

Fig. 7 compares the square wave voltammograms of microparticulate films of: (a) receptors 4-6 in contact with $0.10 \mathrm{M}$ $\mathrm{NaCl}$; (b) receptor 5 immersed into $0.10 \mathrm{M}$ solutions of $\mathrm{NaCl}$, $\mathrm{KNO}_{3}, \mathrm{NaClO}_{4}$, and $\mathrm{K}_{2} \mathrm{HPO}_{4}$, all films being conditioned as previously described. One can see that single-peak responses were obtained in all cases. The variation of the midpeak potential and the open-circuit potential on the concentration of anion for the different modified electrodes in contact with $10^{-4}$ to $0.10 \mathrm{M}$ aqueous solutions of different anion-containing salts immersed produced linear variations of $E_{\mathrm{mp}}$ and $E_{\mathrm{OCP}}$ on the $\operatorname{logarithm}$ of the anion concentration, $\log c$, the slopes of such representations being of $(55 \pm 5) \mathrm{mV}$ per decade, in agreement with the expected Nernstian response. At high concentrations of salt, there are deviations from linearity which can be attributed to the activity/concentration difference already described for this kind of systems. ${ }^{32}$ Such results indicate that these receptors are potentially applicable as sensors for anion determination.

Table 2 summarizes selectivity coefficients for the different anions relative to $\mathrm{HPO}_{4}{ }^{2-}$ anions at $\mathrm{pH}$ values between 7 and 10, calculated from midpeak potential values each of two separate solutions, one containing the ion $\mathrm{X}$ at the activity $a_{\mathrm{X}}$ and the

Table 2 Selectivity coefficients for $\mathrm{HPO}_{4}{ }^{2-}$ anions over the different anions studied

\begin{tabular}{llll}
\hline Anion & $\log K_{\mathrm{A}, \mathrm{B}}(4)$ & $\log K_{\mathrm{A}, \mathrm{B}}(5)$ & $\log K_{\mathrm{A}, \mathrm{B}}(6)$ \\
\hline $\mathrm{ClO}_{4}{ }^{-}$ & $3.9 \pm 0.2$ & $1.8 \pm 0.2$ & $2.0 \pm 0.2$ \\
$\mathrm{~F}^{-}$ & $2.6 \pm 0.2$ & $1.7 \pm 0.2$ & $1.5 \pm 0.2$ \\
$\mathrm{Cl}^{-}$ & $4.4 \pm 0.3$ & $4.4 \pm 0.3$ & $2.2 \pm 0.2$ \\
$\mathrm{Br}^{-}$ & $1.1 \pm 0.2$ & $1.7 \pm 0.2$ & $2.5 \pm 0.2$ \\
$\mathrm{NO}_{3}{ }^{-}$ & $4.0 \pm 0.2$ & $4.2 \pm 0.3$ & $2.4 \pm 0.2$ \\
$\mathrm{HCO}_{3}{ }^{-}$ & $2.0 \pm 0.2$ & $0.5 \pm 0.2$ & $0.5 \pm 0.2$ \\
$\mathrm{SO}_{4}{ }^{2-}$ & $1.4 \pm 0.2$ & $1.7 \pm 0.2$ & $0.7 \pm 0.2$
\end{tabular}




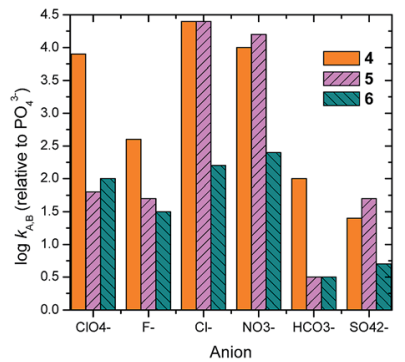

Fig. 8 Selectivity coefficients for $\mathrm{HPO}_{4}{ }^{2-}$ anions over the different anions studied calculated from peak potential values recorded in square wave voltammograms at paraffin-impregnated graphite electrodes modified with 4,5 and 6 in contact with $0.10 \mathrm{M}$ aqueous solutions of different salts, using the separate solution method.

other containing the ion $\mathrm{Y}$ at the same activity. The separate solution method uses the equation: ${ }^{59}$

$$
\log K_{\mathrm{XY}}=\frac{E_{\mathrm{mp}}(\mathrm{Y})-E_{\mathrm{mp}}(\mathrm{X})}{2.303\left(R T / m_{\mathrm{X}} F\right)}+\left(1-m_{\mathrm{X}} / m_{\mathrm{Y}}\right) \log a_{\mathrm{X}}
$$

where $m_{\mathrm{X}}, m_{\mathrm{Y}}$, are the respective formal charges of the ions.

As can be seen in this table and graphically in Fig. 8, a relatively high selectivity was obtained for phosphate anions over all other tested anions using 4 . For 5 and 6, however, a lower selectivity was observed for the $\mathrm{HCO}_{3}{ }^{-}$anion. For $\mathbf{6}$, a lower selectivity for $\mathrm{SO}_{4}{ }^{2-}$ was also detected (see also Fig. 8).

\section{Molecular simulations}

Molecular simulations were carried out in order to rationalize the experimental results. The most stable conformer of the complex was obtained by using Monte Carlo conformational searches followed by a fully optimization with the Merck molecular force field (MMFF) using the Spartan'08 software. ${ }^{48}$ The most stable conformer of complexes from 4 at the different protonation states (i.e. $4, \mathrm{H4}^{+}, \mathrm{H}_{2} 4^{2+}$ ) with different anions $\left(\mathrm{Cl}^{-}\right.$, $\mathrm{PO}_{4}{ }^{3-}, \mathrm{HPO}_{4}{ }^{2-}, \mathrm{H}_{2} \mathrm{PO}_{4}{ }^{-}, \mathrm{SO}_{4}{ }^{2-}$, and $\mathrm{HSO}_{4}{ }^{-}$) were calculated; then the interaction energies were calculated as $E$ (interaction $)=$ $E$ (host-guest complex) $-E$ (host) $-E$ (guest) (Table 3).

Table 3 Interaction energies for the supramolecular complexes of 4 with selected anions at the MMFF level of theory

\begin{tabular}{lc}
\hline Species & $\begin{array}{l}E \text { interaction } \\
\left(\mathrm{kcal} \mathrm{mol}^{-1}\right)\end{array}$ \\
\hline $\mathrm{H}_{2} \mathbf{4}^{2+} \cdot \mathrm{Cl}^{-}$ & -95.65 \\
$\mathrm{H4}^{+} \cdot \mathrm{Cl}^{-}$ & -25.59 \\
$\mathbf{4} \cdot \mathrm{Cl}^{-}$ & 50.74 \\
$\mathbf{4} \cdot \mathrm{PO}_{4}{ }^{3-}$ & -183.55 \\
$\mathbf{4} \cdot \mathrm{HPO}_{4}{ }^{2-}$ & -73.73 \\
$\mathrm{H4}^{+} \cdot \mathrm{HPO}_{4}{ }^{2-}$ & -238.32 \\
$\mathrm{H}^{+} \cdot \mathrm{H}_{2} \mathrm{PO}_{4}{ }^{-}$ & -120.05 \\
$\mathrm{H}_{2} \mathbf{4}^{2+} \cdot \mathrm{H}_{2} \mathrm{PO}_{4}{ }^{-}$ & -198.18 \\
$\mathbf{4} \cdot \mathrm{SO}_{4}{ }^{2-}$ & -133.42 \\
$\mathrm{H4}^{+} \cdot \mathrm{SO}_{4}{ }^{2-}$ & -213.75 \\
$\mathrm{H}_{2} \mathbf{4}^{2+} \cdot \mathrm{SO}_{4}{ }^{2-}$ & -378.41 \\
$\mathrm{H}_{2} \mathbf{4}^{2+} \cdot \mathrm{HSO}_{4}{ }^{-}$ & -180.65
\end{tabular}

Tetrahedral anions like $\mathrm{PO}_{4}{ }^{3-}$ and $\mathrm{SO}_{4}{ }^{2-}$ have a more favorable interaction with the receptor in the different protonation states as experimentally observed according to data in Table 3. For $\mathrm{pH}$ ranges $7-10$ the ligand should be monoprotonated, and the anions should be (mostly) $\mathrm{HPO}_{4}{ }^{2-}$ (in equilibrium with $\mathrm{H}_{2} \mathrm{PO}_{4}{ }^{-}$) and $\mathrm{SO}_{4}{ }^{2-}$. The calculated interaction of $\mathrm{H}^{+} \cdot \mathrm{HPO}_{4}{ }^{2-}\left(-238.32 \mathrm{kcal} \mathrm{mol}{ }^{-1}\right)$ is stronger than for $\mathrm{H}^{+} \cdot \mathrm{SO}_{4}{ }^{2-}(-213.75)$. For acidic $\mathrm{pH}$ values where $\mathrm{H}_{2} 4^{2+}$ is present, the interaction energy of $\mathrm{H}_{2} 4^{2+} \cdot \mathrm{H}_{2} \mathrm{PO}_{4}{ }^{-}(-198.18 \mathrm{kcal}$ $\left.\mathrm{mol}^{-1}\right)$ is stronger than for $\mathrm{H}_{2} \mathbf{4}^{2+} \cdot \mathrm{HSO}_{4}{ }^{-}\left(-180.65 \mathrm{kcal} \mathrm{mol}^{-1}\right)$ (see Fig. 9). An analysis of the number of hydrogen bonds detected as defined by a $\mathrm{NH} \cdots \mathrm{H}$ distance $<2.2 \AA$ reveals that each pair of complexes $\mathrm{H}^{+} \cdot \mathrm{SO}_{4}{ }^{2-} / \mathrm{H}^{+} \cdot \mathrm{HPO}_{4}{ }^{2-}$ and $\mathrm{H}_{2} 4^{2+} \cdot \mathrm{HSO}_{4}{ }^{-} / \mathrm{H}_{2} 4^{2+} \cdot \mathrm{H}_{2} \mathrm{PO}_{4}{ }^{-}$has the same number of $\mathrm{H}$-bonds, 5 and 4, respectively (see Table 4 and Fig. 10). Nevertheless for both pairs the $\mathrm{NH} \cdots \mathrm{H}$ distance is shorter for phosphate species suggesting a stronger interaction with regard to sulfate species.

In order to compare the results from molecular simulations on the studied systems and electrochemical data, the thermochemical cycle depicted in Scheme 4 can be used. Here, the variation of Gibbs free energy for the anion-assisted electrochemical oxidation process, $\Delta G_{\mathrm{EX}}^{\circ}\left(=n F E_{\mathrm{EX}}^{\circ}\right)$, is related with the Gibbs free energies of vaporization of the parent complex, $\Delta G_{\text {vap }}^{\circ}(\mathrm{L})$, and the oxidized form, $\Delta G_{\text {vap }}^{\circ}(\mathrm{LX})$, the corresponding quantities for hydration of protons, $\Delta G_{\mathrm{hyd}}^{\circ}\left(\mathrm{H}^{+}\right)$, and the anion, $\Delta G_{\text {hyd }}^{\circ}\left(\mathrm{X}^{m-}\right)$, receptor protonation, $\Delta G_{\mathrm{LH}}^{\circ}$, oxidized complex ionization, $\Delta G_{\mathrm{i}}^{\circ}(\mathrm{LX})$, interaction between the protonated pseudopeptide and the anion, $\Delta G_{\text {int }}^{\circ}$, and electron transfer from the gas phase to the electrode, $\Sigma_{\mathrm{e}}$, so that:

$$
\begin{aligned}
\Delta G_{\mathrm{EX}}^{\circ} & =\Delta G_{\mathrm{vap}}^{\circ}(\mathrm{L})-\Delta G_{\mathrm{vap}}^{\circ}(\mathrm{LX})+\Delta G_{\mathrm{i}}^{\circ}(\mathrm{LX})+\Delta G_{\mathrm{int}}^{\circ} \\
& -\Delta G_{\mathrm{LH}}^{\circ}-z \Delta G_{\mathrm{hyd}}^{\circ}\left(\mathrm{H}^{+}\right)-\Delta G_{\mathrm{hyd}}^{\circ}\left(\mathrm{X}^{m-}\right)+(m-z) \Sigma_{\mathrm{e}}
\end{aligned}
$$

When comparing the variation of Gibbs free energy for the solid-state, anion-assisted electron transfer process described by eqn (1) for different anions, several of the terms in eqn (10) cancel. In the most favorable case, both anions $\mathrm{X}^{m-}$ and $\mathrm{Y}^{m-}$ have the same charge so that:

$$
\Delta\left(\Delta G_{\mathrm{EX}}^{\circ}\right)=\Delta\left(\Delta G_{\mathrm{i}}^{\circ}(\mathrm{LX})\right)-\Delta\left(\Delta G_{\mathrm{vap}}^{\circ}(\mathrm{LX})\right)-\Delta\left(\Delta G_{\mathrm{hyd}}^{\circ}\left(\mathrm{X}^{m-}\right)\right)
$$
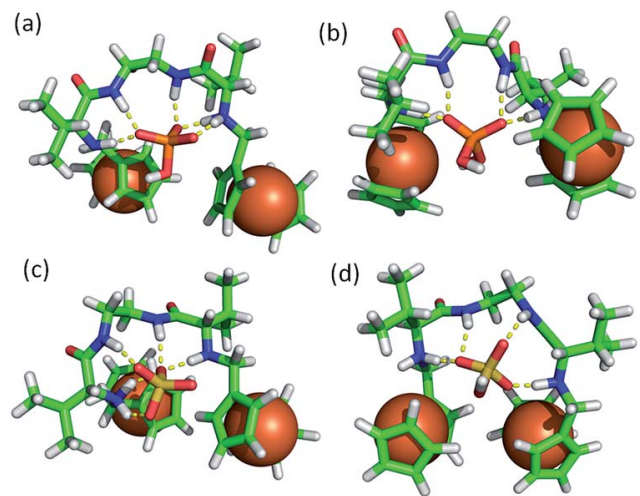

Fig. 9 Optimized structures for the most stable conformers (MMFF): (a) $\mathrm{H}^{4+} \cdot \mathrm{HPO}_{4}{ }^{2-}$, (b) $\mathrm{H}_{2} 4^{2+} \cdot \mathrm{H}_{2} \mathrm{PO}_{4}{ }^{-}$, (c) $\mathrm{H}^{+} \cdot \mathrm{SO}_{4}{ }^{2-}$, (d) $\mathrm{H}_{2} 4^{2+} \cdot \mathrm{HSO}_{4}{ }^{-}$. 
Table 4 Calculated $\mathrm{NH} \cdots \mathrm{H}$ distances $(\AA)$ in $\mathrm{H}$-bonds

\begin{tabular}{lllll}
\hline $\mathrm{H}$-Bond & $\mathrm{H4}^{+} \cdot \mathrm{SO}_{4}{ }^{2-}$ & $\mathrm{H4}^{+} \cdot \mathrm{HPO}_{4}{ }^{2-}$ & $\mathrm{H}_{2} 4^{2+} \cdot \mathrm{HSO}_{4}{ }^{-}$ & $\mathrm{H}_{2} 4^{2+} \cdot \mathrm{H}_{2} \mathrm{PO}_{4}{ }^{-}$ \\
\hline 1 & 1.641 & 1.436 & 1.467 & 1.406 \\
2 & 1.649 & 1.462 & 1.517 & 1.455 \\
3 & 1.722 & 1.567 & 1.822 & 1.644 \\
4 & 1.726 & 1.718 & 1.961 & 1.760 \\
5 & 1.796 & 1.734 & &
\end{tabular}

(a)
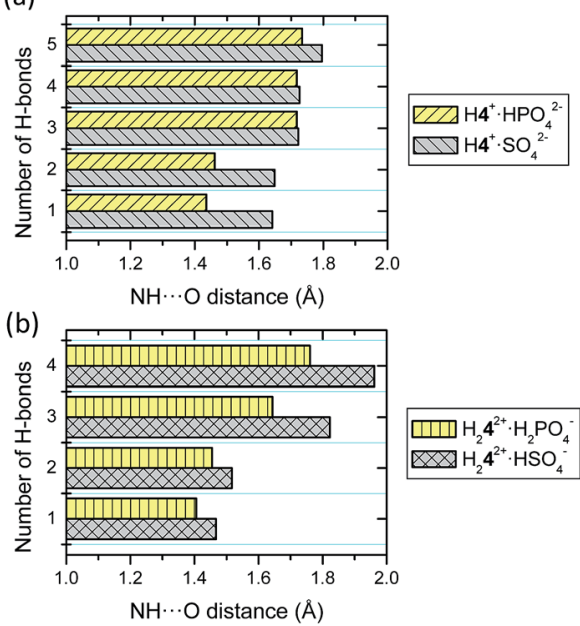

Fig. 10 Graphical comparison of $\mathrm{NH} \cdots \mathrm{H}$ distances in the $\mathrm{H}$-bonds.

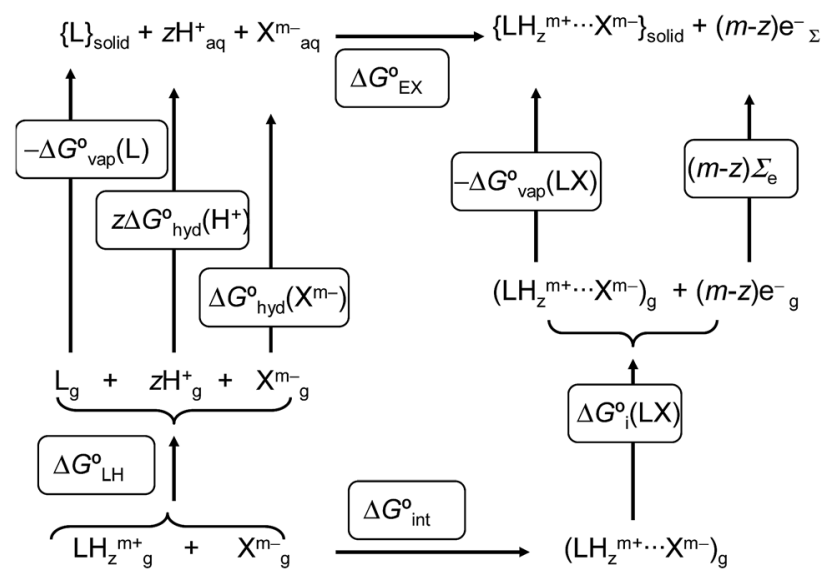

Scheme 4 Thermochemical cycle relating the interaction energy calculated from molecular simulations and the variation of Gibbs free energy for the solid-state, anion-assisted electron transfer process described by eqn (1).

This means that the differences of $\Delta G_{\mathrm{EX}}^{\circ}$ and hence the selectivity coefficients would be dependent on the differences in the interaction energies but also on Gibbs energies of anion hydration and vaporization of the anion-permeated oxidized form. Thus, the differences in hydration Gibbs energies can be correlated with significant variations in the interaction energy, as can be seen in Fig. 11, where the values of $\Delta G_{\text {int }}^{\circ}$ for the

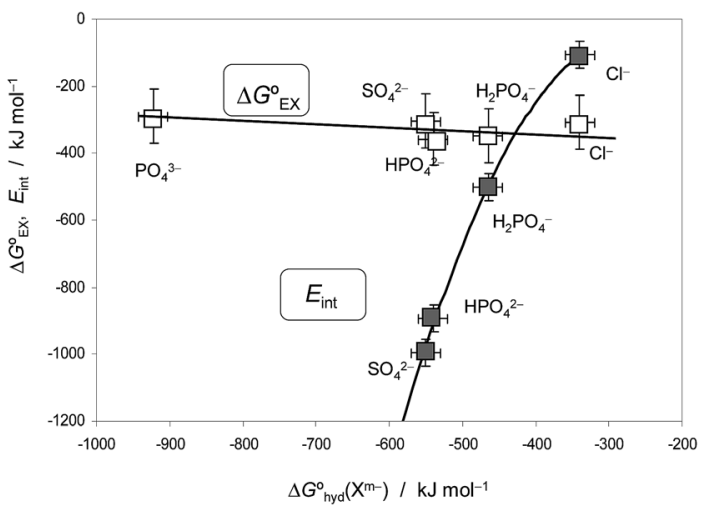

Fig. 11 Variation of the interaction energy calculated from molecular simulations for the interaction of $\mathrm{H}^{+}$with selected anions and $\Delta G_{E X}^{\circ}$ determined from voltammetric data on the $\Delta G_{\text {hyd }}^{\circ}\left(X^{m-}\right) / m$ ratio.

monoprotonated pseudopeptide 4 interacting with selected anions $\left(z=1\right.$ in eqn (1) and (8)) are plotted $v s$. the $\Delta G_{\text {hyd }}^{\circ}\left(\mathrm{X}^{m-}\right) /$ $m$ ratio from tabulated values of Gibbs energies of anion hydration. ${ }^{60}$ In turn, the $\Delta G_{\text {vap }}^{\circ}(\mathrm{LX})$ values should exhibit a significant variation. The result is that the differences in anion hydration Gibbs energy would be, to a great extent, compensated by the corresponding quantities of vaporization of the anion-permeated oxidized form, as can also be seen in Fig. 11.

\section{Conclusions}

Using the voltammetry of microparticles methodology, the studied 4-6 receptors display an essentially reversible oxidation in solid state driven by anion insertion. The open-circuit potential and the midpeak potential recorded in cyclic voltammetric measurements differed for each receptor in contact with $\mathrm{F}^{-}, \mathrm{Cl}^{-}, \mathrm{Br}^{-}, \mathrm{NO}_{3}{ }^{-}, \mathrm{SO}_{4}{ }^{2-}, \mathrm{ClO}_{4}{ }^{-}, \mathrm{H}_{2} \mathrm{PO}_{4}{ }^{-}, \mathrm{HPO}_{4}{ }^{2-}$ and $\mathrm{PO}_{4}{ }^{3-}$ anion-containing solutions. The difference between those potentials permits to separate the individual thermodynamic contributions of electron and proton transfer processes.

Such receptors are potentially interesting for potentiometric sensing, showing relatively high selectivity for $\mathrm{H}_{2} \mathrm{PO}_{4}{ }^{-}$and $\mathrm{HPO}_{4}{ }^{2-}$ anions. Computational studies have been used to provide the corresponding models for the interaction between the corresponding anion species and the receptor $\mathbf{4}$, the one displaying a stronger selectivity between the different anions. For both components of the supramolecular species, the corresponding protonation states, according to the considered $\mathrm{pH}$ ranges, have been taken into consideration. The resulting computational models reveal that receptor $\mathbf{4}$ is exceptionally well suited for the selective interaction with phosphate species, being the interaction significantly stronger than that observed for tetrahedral anionic species derived from sulfate.

\section{Acknowledgements}

Financial support by the Spanish MINECO and FEDER (Projects and Consolider-Ingenio, Projects CSD2010-000652010, CTQ2013-48917-C3-1-P and CTQ2014-53736-C3-2-P) and 
Unidad de Excelencia MDM 2015-0038, and Generalitat Valenciana (PROMETEOII 2015/002) is gratefully acknowledged. V. M.-C. and M. D. P. thank the Spanish Ministry of Science and Education for predoctoral (FPU AP2007-02562) and postdoctoral (SB2010-0088) fellowships. MDP also thankful to UGC India for startup grant. The support of the SCIC of the UJI for instrumental techniques is acknowledged.

\section{Notes and references}

1 K. M. Mullen and P. D. Beer, Chem. Soc. Rev., 2009, 38, 1701. 2 N. H. Evans, C. J. Serpell, N. G. White and P. D. Beer, Chem.Eur. J., 2011, 17, 12347.

3 P. D. Beer, M. R. Sambrook and D. Curiel, Chem. Commun., 2006, 2105.

4 M. D. Lankshear and P. D. Beer, Acc. Chem. Res., 2007, 40, 657.

5 N. H. Evans, C. J. Serpell and P. D. Beer, Angew. Chem., Int. Ed., 2011, 50, 2507.

6 V. Martí-Centelles, M. I. Burguete and S. V. Luis, Chem.-Eur. J., 2012, 18, 2409-2422.

7 Y. D. Wu and S. Gellman, Acc. Chem. Res., 2008, 41, 1233.

8 D. J. Cram, Angew. Chem., Int. Ed., 1988, 27, 1009.

9 V. Martí-Centelles, M. I. Burguete, F. Galindo, M. A. Izquierdo, D. K. Kumar, A. J. P. White, S. V. Luis and R. Vilar, J. Org. Chem., 2012, 77, 490.

10 J. Becerril, M. Bolte, M. I. Burguete, F. Galindo, E. GarcíaEspaña, S. V. Luis and J. F. Miravet, J. Am. Chem. Soc., 2003, 125, 6677.

11 S. V. Luis and I. Alfonso, Acc. Chem. Res., 2014, 47, 112.

12 A. Donoli, V. Marcuzzo, A. Moretto, M. Crisma, C. Toniolo, R. Cardena, A. Bisello and S. Santi, J. Pept. Sci., 2013, 100, 14.

13 M. Bru, I. Alfonso, M. Bolte, M. I. Burguete and S. V. Luis, Chem. Commun., 2011, 47, 283.

14 M. Bolte, M. I. Burguete, S. V. Luis, I. Alfonso, M. Bru and J. Rubio, J. Am. Chem. Soc., 2008, 130, 6137.

15 M. Bru, M. I. Burguete, S. V. Luis and I. Alfonso, Angew. Chem., Int. Ed., 2006, 45, 6155.

16 F. Scholz, Š. Komorsky-Lovrić and M. Lovrić, Electrochem. Commun., 2000, 2, 112.

17 Z. Samec, Pure Appl. Chem., 2004, 76, 2147.

18 R. A. W. Dryfe, Phys. Chem. Chem. Phys., 2006, 8, 1869.

19 J. Langmaier and Z. Samec, Electrochem. Commun., 2007, 9, 2633.

20 A. Sherburn, M. Platt, D. W. M. Arrigan, N. M. Boag and R. A. W. Dryfe, Analyst, 2003, 128, 1187.

21 J. Josserand, G. Lagger, H. Jensen, R. Ferrigno and H. H. Girault, J. Electroanal. Chem., 2003, 546, 1.

22 P. Sun, F. O. Laforge and M. V. Mirkin, Phys. Chem. Chem. Phys., 2007, 9, 802.

23 P. Sun, F. O. Laforge and M. V. Mirkin, J. Am. Chem. Soc., 2007, 129, 12410.

24 A. J. Olaya, M. A. Méndez, F. Cortes-Salazar and H. H. Girault, J. Electroanal. Chem., 2010, 644, 60.

25 R. Gulaboski and F. Scholz, J. Phys. Chem. B, 2003, 107, 5650.

26 F. Scholz, Annu. Rep. Prog. Chem., Sect. C: Phys. Chem., 2006, 102, 43.
27 F. Marken, K. J. McKenzie, G. Shul and M. Opallo, Faraday Discuss., 2005, 129, 219.

28 S. M. MacDonald, M. Opallo, A. Klamt, F. Eckert and F. Marken, Phys. Chem. Chem. Phys., 2008, 10, 3925.

29 R. Cisternas, H. Kahlert, H. Wulff and F. Scholz, Electrochem. Commun., 2015, 56, 34.

30 Electrochemistry of glasses and glass melts, including glass electrodes, ed. H. Bach, F. G. K. Baucke and D. Krause, Springer, Berlin, 2001.

31 F. G. K. Baucke, J. Solid State Electrochem., 2011, 15, 23.

32 A. Doménech-Carbó, I. O. Koshevoy and N. Montoya, J. Solid State Electrochem., 2016, 20, 673.

33 A. Doménech-Carbó, N. Montoya and F. Scholz, J. Electroanal. Chem., 2011, 657, 117.

34 A. Doménech-Carbó, I. O. Koshevoy, N. Montoya, A. J. Karttunen and T. A. Pakkanen, J. Chem. Eng. Data, 2012, 56, 4577.

35 A. Doménech-Carbó, I. O. Koshevoy, N. Montoya and T. A. Pakkanen, Electrochem. Commun., 2011, 13, 96.

36 A. Doménech-Carbó, J. Phys. Chem. C, 2012, 116, 25977.

37 A. Doménech-Carbó, I. O. Koshevoy, N. Montoya, T. A. Pakkanen and M. T. Doménech-Carbó, J. Phys. Chem. C, 2012, 116, 25984.

38 A. Doménech-Carbó, F. Scholz and N. Montoya, J. Phys. Chem. C, 2012, 116, 25993.

39 S. J. Shaw, F. Marken and A. M. Bond, Electroanalysis, 1996, 8, 732 .

40 M. F. Suarez, A. M. Bond and R. C. Compton, J. Solid State Electrochem., 1999, 4, 24.

41 T. J. Wooster, A. M. Bond and M. J. Honeychurch, Electrochem. Commun., 2001, 3, 746.

42 T. J. Wooster, A. M. Bond and M. J. Honeychurch, Anal. Chem., 2003, 75, 586.

43 T. J. Wooster and A. M. Bond, Analyst, 2003, 128, 1386.

44 F. Scholz and B. Meyer, in Electroanalytical Chemistry, A Series of Advances, ed. A. J. Bard and I. Rubinstein, Marcel Dekker, New York, 1998, pp. 1-87.

45 F. Scholz and B. Meyer, Chem. Soc. Rev., 1994, 23, 341.

46 F. Scholz, U. Schröder, R. Gulabowski and A. DoménechCarbó, Electrochemistry of Immobilized Particles and Droplets Monographs in Electrochemistry Series, ed. F. Scholz, Springer, Berlin, Heidelberg, 2nd edn, 2014.

47 A. Doménech-Carbó, J. Labuda and F. Scholz, Pure Appl. Chem., 2013, 85, 609.

48 B. J. Deppmeier, A. J. Driessen, T. S. Hehre, W. J. Hehre, J. A. Johnson, P. E. Klunzinger, J. M. Leonard, I. N. Pham, W. J. Pietro and Y. Jianguo, Spartan'08, build 132 (Mar 27 2009), Wavefunction Inc., 2009.

49 L. O. Abouderbala, W. J. Belcher, M. G. Boutelle, P. J. Cragg, J. W. Steed, D. R. Turner and K. J. Wallace, Proc. Natl. Acad. Sci. U. S. A., 2002, 99, 5001.

50 M. Lovrić and F. Scholz, J. Solid State Electrochem., 1997, 1, 108.

51 M. Lovrić, M. Hermes and F. Scholz, J. Solid State Electrochem., 1998, 2, 401-404.

52 K. B. Oldham, J. Solid State Electrochem., 1998, 2, 367. 
53 M. Lovrić and F. Scholz, J. Solid State Electrochem., 1999, 3, 172.

54 U. Schröder, K. B. Oldham, J. C. Myland, P. J. Mahon and F. Scholz, J. Solid State Electrochem., 2000, 4, 314-324.

55 A. Jaworsky, Z. Stojek and F. Scholz, J. Electroanal. Chem., 1993, 354, 1.

56 M. Hermes, M. Lovrić, M. Hartl, U. Retter and F. Scholz, J. Electroanal. Chem., 2001, 501, 193.
57 P. G. Pickup, C. R. Leidner, P. Denisevich, K. W. Willman and R. W. Murray, J. Electroanal. Chem., 1984, 164, 39.

58 C. P. Leidner, P. Denisevich, K. W. Willman and R. W. Murray, J. Electroanal. Chem., 1984, 164, 63.

59 Y. Umezawa, P. Bühlmann, K. Umezawa, K. Tohda and S. Anemiya, Pure Appl. Chem., 2000, 72, 1851.

60 S. A. Moyer and P. V. Bonnesen, in Supramolecular Chemistry of Anions, ed. A. Bianchi, E. García-España and K. BowmanJames, Wiley, New York, 1997, pp. 1-44. 